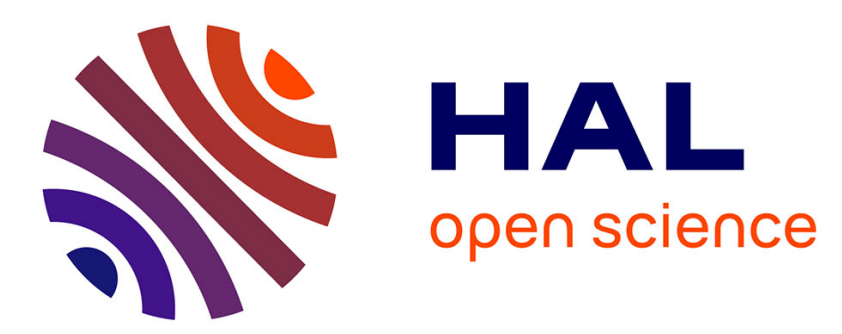

\title{
The Strange Non-Death of Statism: Tracing the Ever Protracted Rise of Judicial Self-Government in France
}

Antoine Vauchez

\section{To cite this version:}

Antoine Vauchez. The Strange Non-Death of Statism: Tracing the Ever Protracted Rise of Judicial Self-Government in France. German Law Journal, 2019, 10.1017/S207183220002318X . hal02736876

\section{HAL Id: hal-02736876 https://hal.science/hal-02736876}

Submitted on 23 Dec 2020

HAL is a multi-disciplinary open access archive for the deposit and dissemination of scientific research documents, whether they are published or not. The documents may come from teaching and research institutions in France or abroad, or from public or private research centers.
L'archive ouverte pluridisciplinaire HAL, est destinée au dépôt et à la diffusion de documents scientifiques de niveau recherche, publiés ou non, émanant des établissements d'enseignement et de recherche français ou étrangers, des laboratoires publics ou privés. 


\title{
Articles
}

\section{The Strange Non-Death of Statism: Tracing the Ever Protracted Rise of Judicial Self-Government in France}

\author{
Antoine Vauchez
}

\begin{abstract}
The article explores the "strange non-death" of the French statist tradition in matters regarding the judiciary. It traces the formation of the specific French model of government of the judiciary describing the stronghold established by the duopole of the Cour de cassation and the ministry of justice's bureaucracy (the so-called Chancellerie) over time (1810-1993) and the failed attempt of the IVth Republic (1946-1958) to unsettle this power balance. It then considers the new context that emerged in the 1990s and analyzes successive reforms that have tried to undermine this deep-seated tradition. In the last part, the article provides an overall assessment of the impact of these reforms on the independence, accountability, and legitimacy of the French judiciary.
\end{abstract}

\footnotetext{
*Antoine Vauchez, CNRS Research Professor, Centre européen de sociologie et science politique, Université Paris 1-Sorbonne. antoine.vauchez@univ-paris1.fr. The research leading to this article has received funding from the European Research Council (ERC) under the European Union's Horizon 2020 research and innovation programme (grant no. 678375- JUDI-ARCH-ERC-2015-STG).
} 
Analyzing the historical trajectory of "judicial self-government" in France (or lack thereof...) calls for a preliminary reflection on the very notion of government or self-government as applied to the judiciary. While the word is routinely used in Italia (autogoverno), in Spanish (autogobierno) or in English, it remains very rare in French. Perhaps unsurprisingly in a country where the fear of the "gouvernement des juges" has haunted the political imaginary for more than two centuries, legal scholars and judges have always preferred the more modest and neutral notion of "administration de la justice". ${ }^{1}$ For the purpose of this research, we would like to depart from this tradition. While the notion of "government of the judiciary" (hereafter GOJ) may seem politically loaded when understood in strict institutional terms, it proves particularly heuristic when given a broader meaning that goes beyond the Conseil supérieur de la magistrature. The notion of government allows for an expansion of the analysis in three directions: first, the broad social, professional and political constellation of actors (high magistrates, judges' unions, politicians, bureaucrats of the ministry of justice, etc.) that get involved and compete over the definition of principles, rules and institutions that (should) govern French judicial profession; second, the various institutional sites where this discussion is unfolding from the parliamentary assemblies to the Cour de cassation or the various administrative departments of the ministry of justice (cabinet, direction du personnel, commissions d'avancement, the Ecole nationale de la magistrature, etc.), the legal scholarship (doctrine) and, last but not least, the Conseil supérieur de la magistrature. Third, the variegated set of instruments through which judges are governed: recruitment, professional careers, vocational training, mobilities outside the profession, disciplinary rules, standards of ethical conduct, etc...

In order to appraise the specific French way of "government of the judiciary" and its transformations over time, one needs to craft a preliminary analytical framework. Admittedly, each form of GOJ embodies a specific assemblage of two essential forms of legitimacy: internal and external. The "internal" form of legitimacy refers to the relative role of statute (hierarchy) or election (unions) as credentials to represent and speak in the name of the judicial profession; the "external" form of legitimacy is a more complex matter as it connects to different possible conceptions of democracy and separation of powers, ranging traditions of direct dependence towards the executive branch (whether it is the ministry of justice or the president of the Republic) to connections with parliamentary assemblies and, to some extent, citizens. ${ }^{2}$ Ever since the late XIXth century, when the judiciary was recognized forms of functional autonomy, all forms of GOJ in Western democracies provide a combination of these two types of legitimacy. Just as there

\footnotetext{
${ }^{1}$ See for example: ThIERRY Renoux \& A. Roux, L'ADMINISTRATION DE LA JUSTICE EN FRANCE, QUE SAIS-JE ? (1994).

${ }^{2}$ Any research that attempts to present French judicial government to an English-speaking audience is faced many historical idiosyncracies and "intraduisibles". This requires to clarify the lexicon from the very beginning: "magistrats" and "magistrature" (hereafter: magistrates and the judiciary) refer to the common statute of those who have been recruited through the concours and trained at the "Ecole nationale de la magistrature". They include both the "magistrats du siege" (hereafter: sitting judges) and "magistrats du parquet" (hereafter: prosecutors).
} 
are no GOJ exclusively grounded on judicial "self-government", there is no system of pure bureaucratic or governmental ruling. As a result, each form of GOJ strikes a particular balance in-between "an unacceptable judicial subordination to politics and an equally unacceptable corporatist ruling" to put it like Paul Coste-Floret, special rapporteur of the constitutional law project on the Conseil supérieur de la magistrature (CSM) in the Constitutional Assembly 1946. This particular combination can be tracked in the composition of the bodies in charge of defining norms and procedures for the judicial profession (eg Conseil supérieur de la magistrature) as well as in the distribution of power regarding disciplinary procedures and the control over professional careers.

The following table sketches, in an ideal-typical manner, various possible combinations of internal and external forms of legitimacy. It allows to delineate four ideal-types. The "Duopole" mode of government refers to a situation, frequent in judiciaries of Napoleonic descent, where the judicial profession is jointly governed by senior magistrates (heads of courts, members of the Cour de cassation) and high civil servants from the Chancellerie (French ministry of justice). The "Popular" ideal-type, most common in parliamentary regimes before the emergence of judicial unionism, is featured by a strong connection of GOJ to parliamentary sovereignty as protection of judges' independence from bureaucracy. The "Democratic" form of GOJ, best embodied by the Italian Consiglio Superiore della Magistratura ever since the $1970 \mathrm{~s},{ }^{3}$ is mostly organized around the actors of representative democracies, namely parties and unions. Last but not least, the "Corporatist" way of governing the judiciary refers to the combination of a strong unionism and a powerful bureaucratic power. None of these ideal-types are to be understood as mirroring reality. Rather they form theoretical fictions that prove useful when it comes to analyze differences across historical configurations.

\footnotetext{
${ }^{3}$ DANiela Piana \& ANTOINE VAucheZ, IL Consiglo superiore della magistratura (2012).
} 
Table 1: Governing the Judiciary. A Conceptual Map

\begin{tabular}{|l|l|l|}
\hline \multicolumn{1}{|c|}{ External Legitimacy: } & $\begin{array}{l}\text { Executive } \\
\text { Ministry of justice } \\
\text { Bureaucracy }\end{array}$ & $\begin{array}{l}\text { Popular } \\
\text { Citizens }\end{array}$ \\
\hline $\begin{array}{l}\text { Hierarchical } \\
\text { Cour de cassation } \\
\text { courts' presidents }\end{array}$ & $\begin{array}{l}\text { "Duopole" } \\
\text { Bureaucratic-Hierarchical } \\
1958-1993\end{array}$ & Political \\
\hline Elective & Corporatist & Democratic \\
Unions & & \\
\hline
\end{tabular}

With this conceptual map in mind, the paper explores how the French way of GOJ has transformed moving across the different boxes of the table. On both the "internal" and the "external" axis of legitimacy, one should not underestimate the epochal transformation underwent by French judiciary. Starting with the first CSM in 1883, it has seen the rise of judicial professionalism leading to the progressive recognition of a role for judges' associations (and later on) unions and lower rank magistrates therein. Initially limited to the judging in the disciplinary system, the scope of self-government have moved progressively to a co-management of professional careers by the CSM and the ministry of justice. Likewise, the paper tracks the transformations of "external legitimacy". The perception of the judiciary has indeed changed dramatically in French public space - in particular from the 1990s onwards. In the context of increasing public distrust in the partisan politics, the judiciary has come to be viewed by many groups as an autonomous institution in-between the State and civil society, with a political legitimacy of its own. As political interferences on judicial affairs were put under the public eye, a variety of governments have attempted to reform the GOJ: in 1993 and in 2008, two substantial constitutional reforms of the Conseil supérieur de la magistrature have been adopted while a number of others, in particular in 1998 and more recently in 2013 have failed, thereby pointing at a state of permanent unrest on the subject matter. As a result, the position of the CSM in the French field of power has changed substantially over time. While it was born in 1883 with very limited power (decisionary power in disciplinary matters) under the umbrella of the Cour de cassation, the Conseil has progressively gained 
jurisdiction over the careers of sitting judges and now - although in part only - over the prosecutors.

However, the paper also points at the fact that the GOJ displays an important level of historical continuity in France. The bureaucratic/hierarchical model of Napoleonic descent that conceives of the judiciary as just one specialized authority under the umbrella of the State has deep professional and institutional roots. ${ }^{4}$ This system of government based on a duopole of the ministry of the justice and the Cour de cassation has perpetuated in spite of the nine changes in political regime that occurred in-between 1810 (when the first statute of the judiciary was adopted) and 1958 (when the Vth Republic was installed). While many social, professional, institutional changes have occurred ever since, none has fully managed to reorient the course of this historical trajectory. Despite many attempts, the Conseil supérieur de la magistrature has never become a full-fledged Council of the "judicial power" (Conseil supérieur de la justice) and there are many elements that indicate the continuous power of the executive branch over the government of the judiciary, in particular (but not only) when it comes to prosecutors. By the many standards, French GOJ is best understood as a co-production of both the CSM and the ministry of justice who form two essential (and competing) junctions between the judicial, the bureaucratic and the political fields.

The article is divided in three parts. First, it explores the formation of French historical tradition of GOJ describing the stronghold established by the duopole of the Cour de cassation and the ministry of justice's bureaucracy (the so-called Chancellerie) over time (1810-1993) and the failed attempt of the IVth Republic (1946-1958) to unsettle this power balance. Second, it considers the new context that emerges with the 1990s and analyzes the succession of reforms that have tried to undermine this deep-seated tradition. In the last part, the article provides an overall assessment of the impact of these reforms on the independence, accountability and legitimacy of the French judiciary.

\section{A. The Duopole Form of Government. From Genesis to (Partial) Crisis (1810-1993)}

If one is to understand the conditions of emergence of French specific way of judicial selfgovernment, he/she has to start with a historical détour into the formation of France's post-revolutionary State. The important 20th April 1810 bill on the organization of the judiciary (loi relative à l'organisation de l'ordre judiciaire et l'administration de la justice) broke with the revolutionary promise that judicial offices, just like any other public office, would become elective, a principle written down "without discussion and unanimously" in the 1790 Constitution ("les juges seront élus par le peuple"). ${ }^{5}$ Fully inserting the judiciary

\footnotetext{
${ }^{4}$ On the strongly rooted professional habitus of administrative and political loyalty within the judiciary, see ALAIN BANCAUD, UNE EXCEPTION ORDINAIRE. LA MAGISTRATURE FRANÇAISE EN FRANCE 1930-1950 (2002).

${ }^{5}$ While the principle has long constituted an authentic act of Republican faith was reactivated in 1848 and then again in 1870 with the IIIrd Republic, and inspired a variety of non-professional tribunals (starting with the cour
} 
into the centralized administrative order that was progressively emerging during the Napoleonic era, the bill turned the judiciary into a bureaucratic body put under the direct control of the executive power. ${ }^{6}$ Reinforced by the various waves of épuration of the higher ranks of the judiciary that has accompanied each regime change across the XIXth century, a structural subordination of judicial activity to the executive power was maintained over time. A duopole progressively emerged that staged the Cour de cassation and the ministry of justice as the two pillars of the government of the judiciary. Critical in this connection was the Parisian fraction of the judiciary that occupied positions alternatively at the ministry of justice (hereafter Chancellerie) and in higher judicial offices -from the Cour de cassation to the courts of appeal, whose access was highly dependent on political connections. Alain Bancaud who has devoted two important volumes to the historical subordination of French judiciary to both politicians and top bureaucrats, has provided the most documented description of the resilience of the power structure that initially coalesced under Napoleonic rule. ${ }^{7}$

\section{Limiting the Rise of Corporatism}

While the IIIrd Republic (1870-1940) initially re-activated the revolutionary act of faith in elected judges, symbolically voting a bill in 1883 that called for the enactment of such principle, it soon took on the same path dependency. Truly enough, the IIIrd Republic did allow for the emergence of forms of judicial corporatism. With the advent of the Republic, newer and lower fractions of the bourgeoisie and the then emerging middle class (the socalled "nouvelles couches sociales" coined by Republican leader Léon Gambetta) entered the judicial body. ${ }^{8}$ Contrary the long dominant profile of local notables that had populated the judiciary all over the XIXth century, the new generations were therefore much more dependent on and wary of "promotion rules" (career stability, professional criteria) and involved in the defense of their professional interests within the State. Following the creation of the first of association of magistrates at the turn of the century, the lineaments of a "public concours" at the entry to the profession were set up in 1906 limiting the access to the judicial profession to those who had received a law degree (the so-called "décret Sarrien", 18th August 1906). This elevation of the threshold weakened the share of heredity that had been so strong in the judiciary all along the XIXth century (the so-called

d'assises), it never became central in French judiciary: FrançoISE LOMBARD, LES JURÉs. JUSTICE REPRESENTATIVE ET REPRESENTATIONS DE LA JUSTICE (1993); L'ELECTION DES JUGES. ESSAI DE BILAN HISTORIQUE FRANÇAIS ET CONTEMPORAIN (Jacques Krynen ed., 1999).

${ }^{6}$ Cf. Benoit Garnot, Histoire de la Justice (2009); Jean-Pierre Royer, Jean-Paul Jean, Histolre de la justice du XVIIeme SIECLE A NOS JOURS (2010).

${ }^{7}$ Bancaud, supra note 4.

${ }^{8}$ Christophe Charle, État et magistrats, les origines d'une crise prolongée, 96-97 ACTES DE LA RECHERCHE EN SCIENCES SOCIALES 39 (1993). 
"noblesse de robe"), ${ }^{9}$ distancing the judicial body from the traditional profile of "a notable, souvent rural, amateur éclairé, recherchant dans les fonctions judiciaires l'autorité et la légitimité d'un poste valorisé plus qu'un revenu". ${ }^{10}$

Yet, this initial movement of professionalization occurred under strict governmental rule. As a matter of fact, the creation of the "concours public" did not undermine the political loyalty of the new recruits. ${ }^{11}$ From the Preliminary Inquiry (Enquête préalable authorizing the candidate to participate to the concours) which involved an assessment of the candidate's political loyalty to the control of the composition of the jury, a variety of mechanisms allowed the executive power to maintain a stronghold over the recruitment of judges. Truly enough, an embryo of self-government did develop in parallel. In 1883, a very first protection was granted to sitting judges with the creation of a new "chamber" of the Cour de cassation, the so-called Conseil supérieur de la magistrature, made of all members of the supreme court, that was in charge of the disciplinary power. Ironically, this first element of self-government was part of a larger bill (loi Martin-Feuillée on judicial organization, 30th August 1883) that suspended for three months the principle of immovability of sitting judges, thereby allowing the Republican government to engage the largest purge of the century with more than 1.000 magistrates leaving the profession.

While an embryo of self-government was recognized, it was under the strict condition that it would remain contained (the CSM only had power in disciplinary matters, leaving the control of professional careers to the other administrative bodies), limited (the newlycreated CSM had no say over parquet magistrates), and purely reactive (the CSM could not open a disciplinary case). ${ }^{12}$ The management of sitting judges' careers was also reformed with the creation in 1906 of the commission de classement headed by the two highest magistrates (President de la Cour de cassation and Chief prosecutor at the Cour de cassation). However, the composition and the competences of the commission were changed many times, in particular in 1908, as a way to secure that the role of the Chancellerie would not be weakened in consequence. Moreover, given the leading role of Cour de cassation and of the Chancellerie in both the commission d'avancement and the CSM, the "Parisian bloc" described by historian Alain Bancaud kept its stronghold. All in all, while the IIIrd Republic did allow for the emergence of forms of corporatism and supported the rise of a professionalism within the judiciary, it certainly never managed to

${ }^{9}$ Id. at $9,39-48$.

${ }^{10}$ Violaine Roussel, AfFaires de JUGES. LeS MAgISTRATS dANS LES SCANDALES POLITIQUES EN FranCE (2002).

${ }^{11}$ On the history of "concours", see CATHERINe FILLON, MARC BONINCHI, DeVENIR JUGE 60-1 (2008).

${ }^{12}$ It should be added that the principle of immovability that had been granted to sitting judges in 1883 did not concern the "magistrature coloniale" who were put on the direct disciplinary jurisdiction of the local "Gouverneur" and of the Prosecution Office (Parquet): see Jean-Paul Jean, Le statut du magistrat de l'entre-deuxguerres à 1958, CAHIERS DE LA JUSTICE (2018). 
upset the traditional symbiotic relationship between the Cour de cassation and the Chancellerie in the government of the judicial body.

\section{Containing Political Ruptures: the Rise and Fall of the IVth Republic Conseil supérieur de la magistrature}

In the long history of the duopole form of government, the IVth Republic (1946-1958) could have marked a sharp rupture. ${ }^{13}$ The 1946 Constitution was a spectacular change of statute for the CSM, echoing in an interesting way transformations that were occurring simultaneously in Italy in the framework of the Assemblea costituente. ${ }^{14}$ By many standards, the CSM was one of the main (if not the main) innovation of the IVth Republic Constitution together with the formal recognition of judges' immovability as a constitutional principle. A whole title of the Constitution ("Titre IX. Du Conseil supérieur de la magistrature") was actually devoted to the CSM that described its new role and competences. Not only was the CSM elevated to the statute of constitutional organ but it was also placed directly under the heading of the president of the Republic -himself brought up to a role of "garant de l'indépendance judiciaire". To be sure, there were elements of continuity with the previous system. Prosecutors were kept out of this transformation remaining strictly under the hierarchical-bureaucratic umbrella of the Chancellerie; and the ministry of justice maintained its "monopoly of proposals" over nominations of sitting judges. Yet, the 1946 Constitution did mark an attempt to undermine the duopole government of the judiciary. For the first time, the CSM moved beyond the realm of disciplinary powers and was granted a decisional power over sitting judges' career, thereby depriving the ministry of justice from a key element of its traditional competences. In addition, Article 84 explicitly granted to the CSM the administration of tribunals and the protection of independence. ${ }^{15}$ The nomination of the Conseil also indicated a sharp rupture with the past: part of the members were elected by the magistrates themselves thereby depriving the Cour de cassation of its monopoly of representation of the judicial body; the other members were chosen by the National Assembly and the Head of State allowing to put the Conseil at bay from the influence of the Chancellerie and the government. All this marked the weakening of the duopole and seemed to delineate an institution able to become a "Conseil du pouvoir judiciaire".

Yet, despite the important investment of the first president of the IVth Republic, Vincent Auriol, in his new role of president of the CSM, over time the duopole effectively managed

\footnotetext{
${ }^{13}$ On this experiment, the best account is: SIMONE BENVENUTI, IL CONSIGLIO SUPERIORE DELLA MAGISTRATURA FRANCESE. UNA COMPARAZIONE CON L'ESPERIENZA ITALIANA (2011).

${ }^{14}$ Piana \& Vauchez, supra note 3.

${ }^{15}$ Article 84 indicates that "le Conseil supérieur de la magistrature assure, conformément à la loi, la discipline des magistrats, leur indépendance et l'administration des tribunaux judiciaires".
} 
to mitigate the effects of the many constitutional innovations. While president Auriol and other members of the CSM repeatedly asked for the transfer of the administrative capacity of the strategic Direction du personnel from the Chancellerie to the CSM, these attempts to implement Article 84 of the new Constitution were met with sharp resistance. As a consequence, the CSM was bound to remain toothless -as it was confirmed by the fact that it was never granted a budget of its own. In this normalization process, the Conseil d'Etat played a critical role. Not only did it make sure that it would not be superseded in the ranking of State authorities and institutions set up in the official order of precedence, but it also contributed to downgrade its statute, by developing a jurisdictional control over the decisions of the CSM, thereby turning the constitutional and supposedly sovereign institution into a mere administrative organ. ${ }^{16}$

\section{The Vth Republic and the Perpetuation the Duopole}

The advent of the Vth Republic (1958-now) marked the end of this twelve years' long experiment. In line with the project of restoration of State authority that inspired the Gaullist regime, the judiciary - that was famously coined as a mere "authority" in the new Constitution - underwent a profound transformation. Mostly inspired by de Gaulle's first minister of justice, Michel Debré (who had already conceived the Ecole nationale d'administration-ENA more than a decade earlier), the many reforms were intended to modernize the judiciary turning it into an efficient administrative body and stripping it from what was perceived as the many archaisms of judicial professions. ${ }^{17}$ In less than 8 months, Michel Debré issued 13 ordonnances and 31 decrees that profoundly rationalized the organization of the judiciary on the model of the professional bureaucracies with the creation of the concours unique (putting an end to the special judicial body that existed for colonies, the so-called magistrature coloniale) and an Ecole nationale de la magistrature in 1959. This new wave of professionalization did not however undermine the executive stronghold over the GOJ. The underlying conception that inspired the letter and the early years' practice of the Vth Republic was famously summarized in the press conference of the de Gaulle on 31st January 1964: "Power proceeds directly from the people, which implies that the Head of State elected by the Nation be the source and the holder (of power). It should of course be understood that the indivisible authority of the State be granted fully by the people to the President and that there be no other authority, neither ministerial, civil, military or judiciary that is not conferred and maintained by it. It is his task to adjust his own supreme domain to the one whose management he attributes to others". ${ }^{18}$ In other words, the judiciary was downgraded to the statute of specialized

\footnotetext{
16 Alain Bancaud, Normalisation d'une innovation. Le Conseil supérieur de la magistrature sous la IVème République, 63-64 DROIT ET SOCIETE 371 (2006).

17 Anne Boigeol, La formation professionnelle des magistrats: de l'apprentissage sur le tas à l'école professionnelle, 76-77 ACTES DE LA RECHERCHE EN SCIENCES SOCIALES 49 (1989).

${ }^{18}$ Unless specificied, translations are mine.
} 
administrative branch placed under the presidential umbrella. Moreover, in the Vth Republic all built around the charisma of the presidential figure, his judicial capacity and power to interfere in the course of judicial affairs was one defining element of its institutional statute. In this context, there was very little place for judicial self-government. Unsurprisingly, the 1958 Constitution turned the CSM into a mere consultative body attached to the president -as indicated in Article 65: "the president is the guardian (garant) of the independence of judicial authority (...); he is assisted par the CSM". Beyond the fact that the CSM lost all its prerogatives in terms of administration of tribunals to the advantage of the ministry of justice, the new Constitution put an end to the election of magistrates' representatives by both the magistrates and the Parliament, replacing it by a nomination of all the members by the president of the Republic. In the new organizational architecture, the secretary general of the CSM, himself a judge directly chosen by the president, was a key figure. Chosen among the presidents' closest collaborators (see Mitterrand's picks), cumulating its position with that of "advisor for judicial affairs" at the presidential office, the secretary general acted as the transmission belt of the executive within the $\mathrm{CSM}^{19}$

The rising concern for the protection of fundamental rights in the 1970 s did contribute to raise awareness on the structural subordination of the judiciary to the executive power. ${ }^{20}$ At the time leader of the main opposition party, the socialist party, François Mitterrand was himself a harsh critic of this state of affairs: "it is the head of State that nominates the members of the CSM; and it is the CSM that nominates the magistrates; that's all". As a matter of fact, the transformation of the GOJ was one of the 110 propositions that formed the electoral platform with which the socialists won both the presidential and the parliamentary elections in 1981. Interestingly however, the initial political impulse for reforms that resulted in the suppression of military tribunals and the abolition of death penalty left the traditional structure of judicial subordination untouched. Despite some initial reform projects, the new socialist government did not alter the traditional duopoleand even used it to a certain extent when it came to avoid the development of judicial inquiries. $^{21}$

\footnotetext{
${ }^{19}$ Alain Bancaud, Le paradoxe de la gauche française au pouvoir: développement des libertés judicaires et continuité de la dépendance de la justice, 44-45 Droit et société 61 (2000).

${ }^{20}$ Pascal Mbongo, la gauche au pouvoir et les libertes publiques (1981-1995) (1999); Eric Agrikoliansky, 'Liberté, liberté chérie...': la gauche et la protection des libertés publiques dans les années 1970. Hypothèses sur la résurgence de la notion d'Etat de droit ", in SUR LA PORTEE SOCIALE DU DROIT: USAGES ET LEGITIMITE DU REGISTRE JURIDIQUE (Liora Israël, Antoine Vauchez, Laurent Willemez eds., 2005).

${ }^{21}$ Alain Bancaud, supra note 19.
} 
The Conseil supérieur de la magistrature over time:

\begin{tabular}{|c|c|c|c|}
\hline & Composition & Competence & Population concerned \\
\hline 1883 & $\begin{array}{l}\text { Cour de cassation in plenary } \\
\text { session }\end{array}$ & Disciplinary & Sitting judges \\
\hline 1946 & $\begin{array}{l}14 \text { members } \\
\text { Pdt: President of the Republic } \\
\text { Vice-pdt: Minister of justice } \\
6 \text { members elected by the } \\
\text { Parliament } \\
4 \text { magistrates elected by their } \\
\text { peers } \\
2 \text { persons chosen by the } \\
\text { president of the Republic }\end{array}$ & $\begin{array}{l}\text { Disciplinary } \\
\text { Administration } \\
\text { of tribunals } \\
\text { Careers }\end{array}$ & $\begin{array}{l}\text { Sitting judges } \\
\text {-High magistrates (proposition } \\
\text { to the president of the } \\
\text { Republic) } \\
\text {-Lower ranks magistrates } \\
\text { (Opinion on the proposals } \\
\text { coming from the ministry of } \\
\text { justice) }\end{array}$ \\
\hline 1958 & $\begin{array}{l}8 \text { members } \\
\text { Pdt: President of the Republic } \\
\text { Vice-pdt: Minister of justice } \\
3 \text { magistrates from Cour de } \\
\text { cassation } \\
1 \text { member of Conseil d'Etat } \\
2 \text { "qualified personnalities" } \\
\text { All chosen by the President of } \\
\text { the Republic }\end{array}$ & $\begin{array}{l}\text { Disciplinary } \\
\text { Careers }\end{array}$ & Sitting judges \\
\hline 1993 & $\begin{array}{l}16 \text { members } \\
\text { Pdt: President of the Republic } \\
\text { Vice-pdt: Minister of justice } \\
\text { Chamber for sitting judges: } \\
5 \text { sitting judges } \\
1 \text { prosecutor } \\
\text { Chamber for Prosecutors: } \\
5 \text { prosecutors } \\
1 \text { sitting judge }\end{array}$ & $\begin{array}{l}\text { Disciplinary } \\
\text { Careers }\end{array}$ & $\begin{array}{l}\text { Sitting judges: } \\
\text {-High magistrates including } \\
\text { presidents of courts of appeal } \\
\text { and presidents of tribunals } \\
\text { (proposition to the president) } \\
\text {-Lower rank } \\
\text { magistrates (binding Opinion } \\
\text { on the proposals coming from } \\
\text { the ministry of justice) }\end{array}$ \\
\hline
\end{tabular}




\begin{tabular}{|c|c|c|c|}
\hline & $\begin{array}{l}\text { All sitting judges and } \\
\text { prosecutors are elected by } \\
\text { their peers } \\
+1 \text { member of the Conseil } \\
d^{\prime} \text { Etat (chosen by the Conseil } \\
d^{\prime} \text { Etat itself) } \\
+3 \text { "qualified personalities" } \\
\text { (chosen by the presidents of } \\
\text { both assemblies and the } \\
\text { president of the Republic) }\end{array}$ & & $\begin{array}{l}\text { Prosecutors: } \\
\text {-High prosecutors (nothing) } \\
\text {-Lower rank prosecutors } \\
\text { (Opinion on the proposals by } \\
\text { the ministry of justice) }\end{array}$ \\
\hline 2008 & $\begin{array}{l}22 \text { members } \\
\text { Pdt: president of the Cour de } \\
\text { cassation } \\
\text { Vice-pdt: chief prosecutor at } \\
\text { the Cour de cassation } \\
\text { Plenary session: } \\
7 \text { magistrates } \\
1 \text { lawyer } \\
\text { (chosen by the national bar } \\
\text { council) } \\
1 \text { member of the Conseil } \\
d^{\prime} \text { Etat } \\
6 \text { "qualified personalities" } \\
\text { (chosen by the president of } \\
\text { the Republic and the } \\
\text { presidents of both } \\
\text { parliamentary assemblies) }\end{array}$ & $\begin{array}{l}\text { Disciplinary } \\
\text { Careers }\end{array}$ & $\begin{array}{l}\text { Sitting Judges } \\
\text {-High magistrates } \\
\text { including presidents of courts } \\
\text { of appeal and presidents of } \\
\text { tribunals (proposition to the } \\
\text { president) } \\
\text { circa } 400 \text { positions } \\
\text {-Lower rank magistrates } \\
\text { (binding Opinion on the } \\
\text { proposals coming from the } \\
\text { ministry of justice) } \\
\text { Prosecutors } \\
\text {-High prosecutors (Opinion) } \\
\text {-Lower rank prosecutors } \\
\text { (Opinion on the proposals by } \\
\text { the ministry of justice) }\end{array}$ \\
\hline
\end{tabular}




\section{B. The Rise of the Self-Government Paradigm and its Discontents (1993-2008)}

\section{The Retreat of the Political}

The 1990s opened up a new phase for the discussion over the government of the judiciary. $^{22}$ It must be said that during the second presidential mandate of François Mitterrand (1988-1995), the general perception of the judiciary changed dramatically in French public sphere. The long tradition of magistrates' political subordination became ever more at odds with the increasing distrust vis-à-vis political actors and institutions (often coined at the time as a "crise de la représentation"). The 1990s were indeed a time of a sharp devaluation of the importance of political commitment in the functioning of certain sectors (media, academic field, judicial unions, etc.) and ramping up of new canons of professional and sectoral excellence that strongly resonated with the criticism of partisan politics. Among these transformations: the progressive move from "journalisme engage" to professional and investigative journalism that turned magistrates into potential allies in the revealing of political corruption; ${ }^{23}$ the governance turn of international organizations (OECD, IMF, World Bank) and NGOs (Transparency International) that led to a renewed interest in the issue of public ethics and deontology; the emergence within the political field itself of "moral entrepreneurs" who called for a "political renovation" through Clean Hands Operations ${ }^{24}$ also contributed to the emergence of this new context.

While relatively independent of each other, these various movements converged in their joint distrust of political parties and governments and their joint expectations that the judiciary be playing new political and social functions from renovation of politics to the modernization of economic regulation, the rights of "usagers" or the protection of fundamental rights etc. ${ }^{25}$ These new hopes were in part met by the rapid blossoming of anti-corruption inquiries. In few years, the reach of judicial investigations actually moved up the ladder of the political hierarchy, rising from political "spade men" and supporters to the very highest level of parties and government. Likewise anti-corruption magistrates gradually penetrated a series of "political sanctuaries". While the first judicial inquiries conducted in the headquarters of political parties were labelled at the time a "judicial burglary" by the then ministry of justice Georges Kiejman, over the years, it has become quite common for prosecutors to search and subpoena political witnesses at the very heart

\footnotetext{
${ }^{22}$ Antoine Vauchez, Judicialization of Politics. Lessons and Questions for the case of the French Fifth Republic, in LAW AND THE FoRMATION OF MOdERN EUROPE 96 (Mikael Madsen \& Christopher Thornill eds., 2014).

${ }^{23}$ Dominique Marchetti, Les révélations du journaliste d'investigation, 131 ACTES DE LA RECHERCHE EN SCIENCES SOCIALES 30 (2000).

24 JUger Le Politique. EnTREPRISES ET ENTREPRENEURS CRITIQUES DE LA POLITIQUE (Jean-Louis Briquet \& Philippe Garraud eds., 2001).

${ }^{25}$ LA FONCTION POLITIQUE DE LA JUSTICE (Jacques Commaille, Martine Kaluszynski eds., 2007).
} 
of the State: virtually no ministry has escaped searches, whether it be the ministry of Finance, Justice, Health, Foreign Affairs, Defense or the Home Office. Only once has this judicial penetration been brought to a halt -and this is related quite unsurprisingly with the presidential figure: this was in March 2001, when President Jacques Chirac refused to respond to a subpoena convoking him as an "assisted witness" in an investigation of embezzlement of funds related to the attribution of public housing contracts by the City of Paris, of which Chirac had been mayor from 1977 to $1995 .^{26}$

A proliferation of writings in legal doctrine and political theory came to theorize the new position of the judiciary. They pointed at the fact that the judiciary would no longer be in the service of the State, but stood in between the State and civil society, protecting the former against the arbitrary of the latter. ${ }^{27}$ In the wake of the anti-totalitarian criticisms that emerged in 1970s within the left, the criticism of the Jacobin Republicanism that structured French political liberalism led to the rehabilitation of the figure of the "third power", now embodied by the judiciary. Elevated to the status of "keeper of the promises $^{\prime 28}$ contained in the constitutional pact, the judicial power was henceforth endowed with a direct political legitimacy. Because all these various sector-specific developments concurred in claiming that this evolution of the judiciary was the transformation they had hoped for, i.e. the advent of a "judiciary power", they were natural allies for one another, and they formed a social platform for the judiciary in the public sphere. The profound legitimacy crisis of both Gaullist and socialist parties as much as the new attention for judicial functions triggered a series of legislative reforms that all marked a retreat of the political (and of the governmental) prerogatives. A January 1995 bill on the financing of political campaigns instated the loss of eligibility to political office for certain offenses -a penalty that would later be applied to former prime minister Alain Juppé. Likewise, a new political custom known as the "Bérégovoy-Balladur jurisprudence" (coined after the name of the former prime ministers) solidified from 1992 onwards to oblige ministers to resign from their cabinet posts if they were indicted (seven ministers were thus forced to resigned between 1992 and the mid-2000s when the custom progressively disappeared).

The voting of the July 1993 constitutional reform of the CSM was an essential part of this wave of reforms through which the political body attempted to restore its legitimacy by giving up some of its attributes in judicial matters. Supported jointly by the left-wing president François Mitterrand and the right-wing prime minister of the time Edouard Balladur, the constitutional law did mark a profound rupture in duopole tradition of government of the judiciary. The executive branch as well as the higher ranks of judiciary

\footnotetext{
${ }^{26}$ Antoine Vauchez, Pouvoir judiciaire, in Nouveau manUel de science Poltidque (2nd ed. 2015).

${ }^{27}$ Denis SALAS, Le TIERS Pouvoir. Vers Une AUtre Justice (1998).

${ }^{28}$ ANTOINE GARAPON, Le GARDIEN DES PROMESSES (1996).
} 
gave up part of their control over the judicial body. This can be seen through the composition of the CSM: while the President of the French Republic and the ministry of justice were sill presiding over the CSM, they did not control anymore the nomination of the other members who were now chosen through election (magistrates) or nomination by presidents of both parliamentary assemblies and the Conseil d'Etat. Likewise, the bill restored the election of a share of the CSM members by magistrates themselves -even though the conditions of elections were featured by an over-representation of higher ranks of the judiciary. One the whole, magistrates actually were in majority with 10 out of 16 members being elected from within the judiciary. The change can also be seen in the competences of the new CSM: the control over careers was considerably reinforced. For the higher ranks of the Bench (the president of the Cour de cassation, chamber presidents at the Cour de cassation, presidents of courts of appeal and also presidents of tribunals), the CSM was actually fully in charge being granted the capacity to make binding nomination proposals to the head of State. For the lower ranks of the Bench, the CSM kept its "Avis conforme", thereby securing a veto power (avis conforme) on the proposals coming from the commission d'avancement of the Chancellerie. Quite importantly, the unity of the judiciary was partially reaffirmed through the inclusion of prosecutors under the jurisdiction of the CSM, albeit in a separate chamber and with purely consultative competences in terms of careers. As the independence of the judiciary became a matter of political debate, some governments even went beyond the letter of the reform. In 1997, the ministry of justice Elisabeth Guigou committed herself to follow the Opinion (Avis) of the Conseil for parquet magistrates' nomination proposals, thereby putting siège and parquet in the same situation (except for the higher ranks of the prosecutors, the so-called procureurs généraux).

\section{The Rise of the Judicial Accountability Paradigm and the 2008 Reform of Self- Government}

The overall context however changed dramatically in the late 2000s. Coming after a series of widely discussed miscarriages of justice ("erreurs judiciaires") in the 1990s and 2000s ("Raddad", "Dils", "Bonal", "Alègre" affairs) that caused public outrage, the 2005 "Outreau scandal" marked a new turn in the public perception of the judiciary moving from a cognitive frame in terms of independence and self-government to a focus on judicial accountability. The scandal concerned a child abuse case in 2004 , in which more than a dozen people were wrongly imprisoned and children were separated from parents from one to three years before being eventually cleared in the appeal before the Cour d'assises in the fall of $2005 .^{29}$ While the prime minister, the minister of justice and the president officially apologized to the wrongly accused persons, a special parliamenty enquiry was set

\footnotetext{
${ }^{29}$ Antoine Vauchez, Le juge, I'homme et la 'cage d'acier'. La rationalisation de l'activité judiciaire à l'épreuve du 'moment Outreau', in LA JUSTICE AU RISQUE DES PROFANES 27 (Hélène Michel et Laurent Willemez eds., 2007).
} 
up in order to "draw the lessons from this judicial fiasco". ${ }^{30}$ This led to the re-mobilization of a set of actors from the media to members of Parliament or bar associations' representatives that all called for a profound reform of judicial accountability and of judicial self-government. With huge public audience and many polls, the public opinion also made a spectacular entry into a debate that had up until new unfolded in semi-public circles: the issue of public confidence/trust in the judiciary became salient. Widely broadcasted on TV and radio, the audition of the juge d'instruction in the case, judge Fabrice Burgaud, fresh out of the Ecole Nationale de la Magistrature marked a climax. Part of the public discussion that unfolded concerned the judicial misconduct, the scope of judicial responsibility and the extent to which the activity of judging itself should be "sanctuarized" or put under scrutiny. The April 2006 decision by the CSM that sentenced judge Burgaud with a mere reprimand (réprimande avec inscription au dossier), the lowest penalty in the magistrates' disciplinary system, further heated the debate pointing at the necessary reformation of judicial self-government and disciplinary system.

While the political interferences in judicial activities had been in large part disqualified in the 1990s in the wave of the anti-corruption inquiries, the "Outreau scandal" gave politicians and media a renewed opportunity to claim a say over the government of the judiciary in the name of the "justiciable". Playing heavily on the rhetoric of "victims" as well as on the need to hold individual magistrates responsible for their misconducts, Nicolas Sarkozy's 2007 presidential campaign and practice as president (2007-2012) led to a series of heated conflicts with unions and the higher ranks of the judiciary, resulting in a unprecedented wave of public demonstrations of magistrates in February 2011.

The new constitutional reform of the CSM adopted on the 23rd July 2008 by one vote of majority by the Parliament in united sessions emerged in this context. Truly enough, the reform of the Conseil is only one part of an overall modernization of the Vth Republic's Constitution initially designed by an expert committee headed by former prime minister Edouard Balladur (Comité de réflexion et de proposition sur la modernisation et le rééquilibrage des institutions, the so-called "Comité Balladur" of October 2007). In the case of the CSM however, the changes were very much in line with the discussion that had taken place in the Parliament in the wake of the "Outreau affair". The risks and flaws of judicial corporatism were pointed out by the comité Balladur: "the 1993 reform has not reached its objectives as it has not put an end to the conflicts between the government and the CSM; despite the letter of the texts (constitutional and legislative), the CSM has established a so-called "plenary session" whose existence has fueled the criticism of corporatism too often addressed to the judicial institutional". ${ }^{31}$ As a consequence, the new

${ }^{30}$ Philippe Houillon, Rapport fait au nom de la Commission d'enquête chargée de rechercher les causes des dysfonctionnements de la justice dans l'affaire dite d'Outreau et de formuler des propositions pour éviter leur renouvellement, Assemblée nationale, June 2006.

${ }^{31}$ Comité de réflexion et de proposition sur la modernisation et le rééquilibrage de la Vème République présidé par M. Edouard Balladur, Report to the president of the Republic 78 (October 29, 2007). 
institutional design downsized the role of magistrates who actually do not constitute a majority in the Conseil anymore. In each one of the two specialized chambers of the CSM (Sitting judges and Prosecutors), the "lay members" (i.e. chosen from outside the judiciary) were made more numerous (8/15) than the elected representatives of the magistrates (7/15). At one and the same time, the capacity of the institution to act as the spokesman of the judicial power was circumscribed: while the 2008 reform recognizes the possibility of "plenary sessions", it tries to channel a practice that had raised the fear of an emerging judicial power. ${ }^{32}$ The current Article 65.8 officializes such practice but makes sure that in case the CSM would meet in plenary session, magistrates remain in minority.

This did not mean however that the 2008 reform marked a return to the pre-1993 situation. As a matter of fact, the president and the ministry of justice did not re-gain any competence: to the contrary, they were further marginalized as they were no more part of the Conseil itself. Symbolically, the CSM left the presidency's buildings where it had met ever since 1946 (Quai Branly) and moved for the first into buildings of its own (Hotel Moreau). The overall project was more geared towards establishing a broader public and professional accountability of the judiciary. ${ }^{33}$ As a way to give voice to representatives of the "justiciables", new members were called upon to take part to the Conseil, in particular a lawyer chosen by the representative body of the legal profession (Conseil national des barreaux) and six "personnalités qualifiées (PQ)" who could not belong either to the judiciary, the Parliament and the administration and were chosen by political authorities (the president of the Republic, president of the lower and the higher chamber). Interestingly, the parliamentary committees of the National Assembly and of the Senate were given the possibility to audition these six $\mathrm{PQ}$ and eventually block their nomination by a qualified majority. Another important aspect in this regard lies in the opening of a new procedural pathway for the opening of disciplinary proceedings. Up until 2002, only the ministry of justice could open a disciplinary case: while a first opening had occurred in 2002 as the capacity to initiate a case was extended to heads of tribunals, the 2008 constitutional reform opened this possibility to the litigants themselves. As stated in the Loi organique of 22 July 2010 that enacted the constitutional reform: "Any party who considers during proceedings to which she is a party that the behavior of a judge could be qualified as a disciplinary issue may call upon the Conseil supérieur de la magistrature to

\footnotetext{
32 It should be remembered that in 1994, the president of the Republic asked the Conseil to meet in plenary session asking for advice; later on, the CSM spontaneously gathered in full composition a couple of times, thereby claiming to be a legitimate interlocutor of political power and of the judicial body.

${ }^{33}$ In terms of careers, there was little change except for prosecutors: while up until 2008, the CSM was entirely kept outside of the nomination of higher positions of prosecutors (ie the nominations decided in the framework of the Conseil des ministres), the reform introduced a compulsory yet non binding Opinion of nomination proposals from the CSM.
} 
intervene." ${ }^{34}$ The effect of the 2008 innovation seems up to now to have remained rather limited in size given the filtering role of the commission d'admission des requêtes (CAR) composed of two magistrates and two "lay members". ${ }^{35}$ In this context, the fear expressed by many unions of exposing magistrates to the "tribunal de l'opinion" was surely exaggerated. The most recent data indicate that the number of complains has remained rather stable over time (around 200-250 per year); the filtering role of the CAR has been stringent with only 46 cases out of the total of 1751 registered between 2011 and 2016 considered admissible. Out of these 46 cases, only five individuals (one procureur de la République and four judges) have been brought to the section in charge of disciplinary pursuits within the CSM. ${ }^{36}$

The Conseil supérieur de la magistrature ever since the 2008 Reform:

\begin{tabular}{|c|c|}
\hline \multicolumn{2}{|c|}{ Specialized Sessions } \\
\hline $\begin{array}{l}\text { Sitting judges' Chamber } \\
\text { (15 members for Nominations matters) } \\
\text { (15+1 for Disciplinary matters) }\end{array}$ & $\begin{array}{l}\text { Prosecutors' Chamber } \\
\text { (15 members for Nominations matters) } \\
\text { (15+1 for Disciplinary matters) }\end{array}$ \\
\hline $\begin{array}{l}\text { President of the Cour de cassation } \\
\text { (president) }\end{array}$ & $\begin{array}{l}\text { Chief Prosecutor at the Cour de cassation } \\
\text { (president) }\end{array}$ \\
\hline 5 sitting judges (elected) & 5 prosecutors (elected) \\
\hline 1 prosecutor & 1 sitting judge \\
\hline \multicolumn{2}{|c|}{$\begin{array}{l}\text { Lay members } \\
1 \text { member of the Conseil d'Etat (chosen by the Conseil d'Etat) } \\
1 \text { lawyer (avocat) } \\
6 \text { Qualified personnalities chosen outside of the judiciary } \\
\text { (chosen by the president of the Republic, the president of the National Assembly, the } \\
\text { president of the Senate) }\end{array}$} \\
\hline
\end{tabular}

\footnotetext{
${ }^{34}$ Translated by the author. Original text: “Tout justiciable qui estime qu'à l'occasion d'une procédure judiciaire le concernant le comportement adopté par un magistrat dans l'exercice de ses fonctions est susceptible de recevoir une qualification disciplinaire peut saisir le Conseil supérieur de la magistrature".

${ }^{35}$ On the conditions of admissibility (and rejection) of these claims, see MICHEL LE POGAM, LE CONSEIL SUPERIEUR DE LA MAGISTRATURE 29-32 (2014).

${ }^{36}$ Data from the 2016 Report of the CSM, at 85.
} 
Plenary Sessions

Presided over by the Premier president de la Cour de cassation (the Procureur général as deputy)

3 sitting judges

3 prosecutors

8 lay members (supra)

\section{C. "Une Constance Mobile"? Assessing the Current State of the Government of Judiciary}

Ever since the early 1990s when the issue of the judiciary became more and more politically salient, the GOJ has entered a phase of continuous transformations. As the political framing of the stake of judicial reform kept on changing over time (from the promotion of the fight against political corruption to the prevention of judicial miscarriages, from right wing governments more inclined in promoting magistrates' liability to left-wing governments more interested in promoting the independence of the judiciary), different waves of proposals emerged for the reform of the CSM. Yet, interestingly enough, despite this erratic pattern of reforms, the trajectory of French GOJ has remained in substance unaltered. To a certain extent, it even appears as a "constance mobile", to paraphrase Alain Bancaud's caracterization of late XIXth century Cour de cassation, as the general asset of co-management between the ministry of justice and the CSM was proving resilient despite constant institutional changes.

Hereafter, we provide substantial evidence for this pattern as we consider the independence, accountability and legitimacy and French GOJ.

\section{Independence}

Given the fuzziness intrinsic to the notion of "independence", ${ }^{37}$ it is almost impossible to provide a substantial assessment of its changing "levels" within French judiciary. Hereafter we have chosen a narrow definition thereof, one that points at the institutional deadlocks through which the executive branch maintains forms of control over the government of the judiciary (nominations, career promotions, possibilities of interfering in the course of a case, etc.). In this regard, the overall narrative of progress that points at the uninterrupted

\footnotetext{
37 Isabelle Boucobza, L'énigme de l'indépendance des juges en France, in POLITIQUE DE L'INDEPENDANCE (Bastien François, Antoine Vauchez eds., 2018).
} 
rise of judicial self-government and the progressive retreat of the "political" is well grounded. However, the issue remains more complex to settle. As we have seen all along our historical excursus, not all reforms have been geared towards the attempt to put the CSM at more distance from political bodies. Others such as the 2008 one, have targeted other objectives -starting with an overall reinforcement of magistrates' liability. Moreover, the "rise and rise" narrative of progress also overshadows the striking elements of continuity with the deep-seated duopole tradition of government.

All in all, careers of sitting judges are still co-managed by the CSM and the Chancellerie. The CSM certainly gained an important say on the career moves from the first nomination at the exit of the Ecole nationale de la magistrature to changes in function within one tribunal or the moves outside of the judiciary. However, it is far from being an exclusive competence as careers remain a matter of shared competences with other administrative bodies of the ministry of justice -from the Direction des services judiciaires ${ }^{38}$ of the Chancellerie to the commission d'avancement. ${ }^{39}$ The latter which is partly elected by judges and partly composed of top civil servants of the Chancellerie (coming from both the General Inspectorate and Directorate of Services judiciaires administration) still retains important competences at the early stage of the career -as it is in charge of establishing the "tableau d'avancement" listing the judges with more than 10 years of service who are entitled to apply for higher judicial offices. ${ }^{40}$ The former still keeps the monopoly of proposition (to the CSM) for most judicial nominations: except for the higher ranks of the Bench, i.e. circa 400 sitting judges, in $95 \%$ of the nomination cases, ${ }^{41}$ the CSM has no control over the list of candidates on whom it is going to give its Avis. In a series of widely discussed interventions, the current first president of the Cour de cassation and currently president of the CSM has asked that "all sitting judges be nominated on the initiative of the CSM". ${ }^{42}$ The problem is however more profound that the Direction des services judiciaires (DSJ) also concentrates most of the expertise when it comes to "human resources" in particular thanks to a rich toolbox of statistical and computer instruments. Despite being an organ of constitutional rank, the CSM is deprived of direct access to the DSJ toolbox of

38 The Direction des services judiciaires is the directorate of the ministry of justice in charge of all organizational/administrative matters related to tribunals and magistrates.

${ }^{39}$ It should also be said that courts' presidents have retained an important role as they are the ones in charge of the yearly individual assessment of judges. More broadly, they have important administrative powers -in terms of organizing the daily allocation of cases and the overall organization of the court- that can constitute a threat to judges' independence. See Antoine Garapon \& Harold Epineuse, Judicial Independence in France, in JUDICIAL INDEPENDENCE IN TRANSITION 273 (Anja Seibert-Fohr ed., 2012).

${ }^{40}$ The commission d'avancement also decides over the recruitment of magistrates through derogatory procedures (a pathway which has been increasingly used to recruit magistrates over the past decade).

${ }^{41}$ Cf. Michel Le Pogam, former member of the Conseil in his well documented book on the Conseil, supra note 35.

${ }^{42}$ Bertrand Louvel, Pour échapper à la suspicion, il faut modifier le système de nomination des juge, LE MONDE (May 30, 2016). 
statistical instruments and computer software that would allow the CSM to get a clearer picture of the context of a tribunal or of specific judicial function to which a judge is nominated. These various deadlocks seem to be all the more important that, in its constant practice, the Conseil has shown to be very cautious in rejecting the ministry's nomination proposals. A recent report from the CSM pointed out that, for the 2006-2012 period, out of the circa 1100-1300 nominations' proposals examined every year, only 25 to 41 cases had been given negative Opinions ("Avis non conformes") by the CSM. ${ }^{43}$ The same could be said about prosecutors since, out the 550 to 650 nominations' proposals considered at CSM, only from 5 to 15 received negative avis every year. On the whole, the CSM has limited its veto power vis-à-vis the Chancellerie's proposals to $2-3 \%$ of the cases.

The most striking case of continuity in the duopole tradition of government remains that of the parquet magistrates. Only in 1993 was the Conseil granted a competence (albeit at the time merely "consultative") over the careers of prosecutors. Up until then, the matter was dealt exclusively within the ministry of justice. Ever since, a number of constitutional reform proposals, starting with the ones put forward by socialist governments in 1998 and in 2013, have been targeted at turning the Opinion (Avis simple) given over nominations' proposals made by the ministry of justice into a binding Opinion. ${ }^{44}$ The 2013 reform project even ambitioned to give the CSM a substantial role in terms of discipline (not just consultative as is the case now). ${ }^{45}$ Similarly, it aimed at giving the CSM a real role in matters of disciplinary control over prosecutors, turning the CSM into a "disciplinary council of prosecutors". While both 1998 and 2013 proposals were abandoned due to the lack of qualified majority required for constitutional reforms, their failure also refer to a general reluctance within French political and legal culture to align the statute of parquet judges with that of sitting judge. The recent and much expected decision of the Conseil constitutionnel (CC) on the issue of independence of parquet magistrates is very telling in this regard as it recognizes at one and the same point the independence of parquet magistrates and... their political dependence to the government: "The Constitution establishes the independence of prosecutors, which implies that they freely exercise of their activity in jurisdictions, that this independence has to be conciliated with the prerogatives of the government and that it is not secured by the same safeguards as the ones applicable to sitting judges". ${ }^{46}$

\footnotetext{
${ }^{43}$ Data CSM report 2017, at 20-21.

${ }^{44}$ It should be said, however, that despite the repeated failures of these constitutional reforms, the institutional practice over the past decades has seen no nomination of prosecutors that had receive an "avis défavorable" from the CSM.

${ }^{45}$ It should be added that president Macron has announced during his campaign a profound constitutional reform of the role of prosecutors that would cut the transmission belt with government. Given the absence of the threefifth majority in the two parliamentary assemblies required for constitutional revisions, the reform seems unlikely.

${ }^{46}$ Conseil constitutionnel, Décision $n^{\circ}$ 2017-680 QPC (Dec. 8, 2017).
} 
Beyond career issues, the French CSM is far from being able to claim a form of speakership in the name of the "judicial power" the way the Italian CSM has managed to do over time. ${ }^{47}$ One of the reasons lies in the fact that the CSM has found very few supporters in the public debate. Quite expectedly, judicial unions have been the Conseil's staunchest supporters. While the two judicial unions, the left-wing Syndicat de la magistrature and the more moderate Union syndicale des syndicats differ both in terms of political leanings and in terms of connections with social movements and civil society, they are equally promoting both internal and external independence. Claiming more than 2200 members out of the circa 8000 judges, the Union syndicale des magistrats, a union born in 1974 out of the old Union fédérale des magistrats (created in 1945), still holds a large majority within the judiciary (between $62 \%$ and $72 \%$ of the votes at the election of judges' CSM representatives ever since 2002). ${ }^{48}$ While the Syndicat de la magistrature has remained in minority (from $27 \%$ to $31 \%$ of the votes in the last four CSM elections), it is still influential through its publications (J'essaime and Délibérée) and its many connections with the network of human rights' organizations (Ligue des droits de I'homme, Amnesty, etc.). ${ }^{49}$ However, over the years, their joint commitment in the defense of judicial independence has found little support within the political body and in the media.

Relatedly, the CSM has hardly moved beyond the realm of disciplinary power and career management, leaving to the side subject matters that are usually considered to be critical for self-government: recruitment of judges (particularly through the so-called concours complémentaires that recruit judges on the based of previous professional experience), ${ }^{50}$ initial and vocational training (the Judicial Academy - the Ecole nationale de la magistrature - is placed under the "tutelle" of the minister of justice who nominates its director), professional moves in national, European, or international administrations (détachement), or in the private sectors, etc. Moreover, the legislator has continuously curbed all attempts by the CSM to take a direct part in the public discussion. The reluctance of political actors to grant such a role can be seen in all the political resistances against the development of CSM "plenary sessions". While the 2008 reform has for the first time officially recognized an advisory function to the CSM through its "Opinions" upon demand from the head of State or the ministry of justice, it however did forbid any "spontaneous" intervention of the Conseil in the public debate. Interestingly enough, this

\footnotetext{
${ }^{47}$ Piana \& Vauchez, supra note 3.

${ }^{48} \mathrm{See}$ the results at http://www.union-syndicale-magistrats.org/web2/themes/fr/userfiles/fichier/reserves/ elections/csm/csm2014_resultats.pdf.

${ }^{49}$ On judicial unionism in France, see the special issue Faut-il craindre le syndicalisme judiciaire, 3 CAHIERS DE LA JUSTICE (2016).

${ }^{50}$ On these procedures that account for the recruitment of $26 \%$ of the magistrates, see http://www.giprecherche-justice.fr/wp-content/uploads/2014/07/10-31-RF.pdf.
} 
reluctance seems to be shared by the Conseil constitutionnel which censured an article of the Loi organique 22 July 2010 which granted the CSM with an autonomous capacity to intervene. On the whole then, the CSM "speaks" very little. It is not until 1993 that the CSM has started publishing a Rapport annuel presenting its activities, explaining its policies (criterias, guidelines, cases, etc.) and providing special thematic inquiries (in the field of deontology, public opinion towards the judiciary, etc.), the way all other high councils and supreme courts have do for a long time (in particular the Conseil d'Etat).

Overall, the dominant conception of the Conseil superieur de la magistrature remains that of an administrative organ, far from the constitutional statute of a sovereign Council of judicial power. Truly enough, the CSM has emerged as a more autonomous institution over the past two decades. Just to mention one emblematic indicator in this direction, a Loi Organique of the 22nd July 2010 has granted budgetary autonomy to the Conseil which now has a budget separate that its president negotiates directly with the bureaucracy of the ministry of finance and discusses in auditions before the finance committees of both the Senate and the National Assembly. ${ }^{51}$ However, no reform has actually ever changed the fact that CSM is considered in the Constitution as the "assistant" to the president of the Republic in its mission of "garant de l'indépendance de la justice" (art. 64). In line with its historical attitude vis-à-vis the $\operatorname{CSM}^{52}$ the Conseil d'Etat has even consolidated this modest definition of the French way of self-government. While its intervention may have contributed to reinforce guarantees protecting magistrates' defense rights in the context of disciplinary sanctions, it has brought the CSM under its jurisdictional umbrella, limiting the effects of the various constitutional innovations that had granted it a constitutional statute. From 1953 Falco et Vidaillac decision to a more recent Gengis Khan decision of 29 October 2013, the Conseil d'Etat has developed its jurisdiction control over CSM decisions. In the 2013 arrêt, the Conseil d'Etat has decided that it was competent to review the "Avis non conforme" delivered by the CSM -thereby opening an entirely new pathway for the supervision of the CSM, confirming the role of the Conseil d'Etat as a "court of appeal" of the CSM proceedings and limiting the latter's autonomy. ${ }^{53}$

\section{Accountability}

The magnitude of change should also be qualified when it comes to the issue of judicial accountability. While the legal grounds on which French magistrates' conduct are judged in the context of disciplinary control have always been rather vague, the institutional practice

\footnotetext{
${ }^{51}$ Up until then, the budget of the CSM was part of the general budget of the judiciary and its resources were therefore granted and decided over by the Ministry of justice (the head of the Direction des services judiciaires).

${ }^{52}$ Alain Bancaud, supra note 19.

${ }^{53}$ By many standards, the Conseil d'Etat is a 'court of appeal' for individual magistrates as they can appeal before it all individual decisions regarding issues of nomination, career, professional assessment, sanctions, etc.
} 
as much as the CSM disciplinary jurisprudence has remained rather restrictive in terms of the scope of judges' responsibility. More importantly, as New Public Management policies were progressively hitting the judiciary, the role of both the hierarchy and the ministry has ironically been reinforced through their increasing role in the management of the judicial body.

Article 43 of Ordonnance of 22 December 1958 (the statute of the judiciary), still the main legal ground for disciplinary complaints, provides a very broad definition of what constitutes a "disciplinary fault": "tout manquement par un magistrat aux devoirs de son état, à l'honneur, à la délicatesse ou à la dignité, constitue une faute disciplinaire". Truly enough, over the years, a jurisprudence has consolidated within CSM disciplinary chambers (but also at the Conseil d'Etat) that has helped specified these rules and principles: ever since 2006, the CSM publishes an updated Recueil des décisions disciplinaires (accessible online) bringing together all disciplinary decisions ever since 1958. Even though the activity of the disciplinary section has increased rapidly over the past 15 years, moving to a rhythm of 51 decisions per year between 2000 and 2009 (for both the prosecutors and sitting judges). ${ }^{54}$ it still remains rather modest -in part due to the stringent filtering role of the commission d'admission des requêtes (CAR) of litigants' complaints ever since 2008.

Important limits have been put to the scope of judicial responsibility. In a series of important decisions, the Cour de cassation has expressly excluded the content of judicial decisions from the realm of criminal responsibility: "in virtue of the constitutional principle which guarantees the independence of magistrates, their judicial decisions can be criticized in terms of motives only through the judicial remedies organized by the law; this principle, just as the secret of judicial deliberation, prohibit that a judicial decision be considered as constituting in itself a crime or an offense" ${ }^{55} \mathrm{~A}$ similar principle has been developed by the CSM in its disciplinary powers: "magistrates' procedural acts can only be criticized by using the judicial remedies organized by the law for the parties to the trial" ${ }^{56}$ However, in the wake of the "Outreau affair" and what has been viewed as judge Burgaud's personal responsibility in the case, the Parliament has made a first breach indicating as a possible disciplinary ground "a serious and intentional violation by a magistrate of a procedural rule which constitutes an essential guarantee of the parties as certified by a judicial decision": ${ }^{57}$ however, at the stage, no disciplinary claim has been made on this new ground. ${ }^{58}$

\footnotetext{
${ }^{54}$ Michel Le Pogam, supra note 35, at 52-61.

${ }^{55}$ Cour de cassation, Crim. (Dec. 9, 1981).

${ }^{56}$ CSM, decision S57 (Dec. 12, 1991), Recueil des décisions disciplinaires, la documentation française 243 (2004).

${ }^{57}$ Loi Organique of 22 July 2010.

${ }^{58}$ Michel Le Pogam, supra note 35, at 52-61.
} 
However, while the disciplinary, civil and criminal forms of responsibility have remained rather weak, ${ }^{59}$ the judiciary has been touched by the emergence of new standards of accountability for public service. Despite the traditional claim that the judicial activity is not measurable, the rapid diffusion of New Public Management (NMP) within the French bureaucracy has profoundly transformed the benchmarks and policy instruments through which the "quality" of justice is being perceived and assessed. ${ }^{60}$ It is not the place here to chronicle the process through which this managerial turn has hit French judiciary from the late 1990s onwards. It is however important to note its destabilizing effects over the government of the judiciary as a variety of think tanks, media and business actors promoting this NMP turn have pointed out the archaic corporatism that lied underneath the professional "rhetoric" of independence. ${ }^{61}$ The two important reforms that have marked the development of NMP in French administration (the new Loi Organique sur la Loi de Finances-LOLF in 2001 and the Revue générale des politiques publiques-RGPP in 2007) have turned the judiciary into one of the 34 "Missions" of the State, identifying a set of Programmes, Objectives, and eventually Indicators of performance in terms of "flux", "stocks", "average length" of trials. A whole culture of auditing and management diffused within the judicial institution bringing to the forefront a rhetoric of "users" (usagers) and a toolbox of software allowing for central supervision of the performance of tribunals and the advancements of dossiers (Cassiopée et Pharos) by presidents of tribunals and by the Chancellerie. Although it did raise concerns and protests among magistrates, a "wage premium" on the basis of productivity has been introduced on the basis of judges' productivity. ${ }^{62}$ Just like in all NMP reforms, this has come along with a process of centralization that reinforced the role of heads of jurisdictions and of the Chancellerie. While the latter increased its governing capacity with the creation in 2005 of a position of secretary general in charge of coordinating the modernization of the judicial body, the former have been given the task to allocate the new wage premium -notably on the basis of judges' performance. On the whole then, the duopole of courts' presidents and the

\footnotetext{
59 To that must be added the "deontological turn" that has touched the judiciary. In 2005, a Rapport of the Commission de réflexion sur l'éthique dans la magistrature (Commission Cabannes) was commissioned by the ministry of justice. In the reform of the judiciary that directly derived from the "Outreau affair" (Loi organique du 5 March 2007), the Parliament asked the CSM to write a Recueil des obligations déontologiques du magistrat. The volume that came out in 2010 and has been regularly revised ever since is not a Code; it provides mostly guidelines of what is a "normal professional behavior". This has now become one of the prerogatives of the CSM. A doctrine has emerged around the " 3 I" pilar: independence, impartiality and integrity to which the CSM has added "attention à autrui", "discretion" and "reserve". It was clearly part of an overall phenomenon of "responsabilisation" of public officials.

${ }^{60}$ On this, see ANTOINE VAUCHEZ \& LAURENT WILLEMEZ, LA JUSTICE FACE A SES REFORMATEURS. ENTREPRISES DE MODERNISATION ET LOGIQUES DE RESISTANCE (2007).

${ }^{61}$ For an example, see the report from the liberal conservative think tank Institute Montaigne, Pour la justice (2004), http://www.institutmontaigne.org/publications/pour-la-justice.

${ }^{62}$ Elise Chelle, Une politique de récompense dans la haute magistrature: le cas de la prime de rendement, 78 DROIT ET SOCIETE 407 (2011).
} 
Chancellerie is the clear winner in the spectacular rise of managerial accountability within the judiciary over the past decade.

\section{Legitimacy}

When it comes to legitimacy, change is certainly even more difficult to measure. In contemporary democracies, public opinion as measured by polls constitute the most common proxy for legitimacy. However, the relationship between the judiciary and the public opinion is a complex one and certainly hard, if not impossible, to decipher. To be sure, professionals of the judiciary traditionally have a strong reluctance to even consider "public opinion" given the fact that their very activity is supposed to be independent from any form of public pressure. However, over the past decades, the relationship of public institutions to the general opinion has become more complex. Ever since the 1970s when judicial unions were calling for more connections with civil society, ${ }^{63}$ judges have increasingly taken stances in the public debate, even launching Manifestos and Public Calls (see for example back in the 1990s, the Geneva call of anti-corruption judges). Moreover, in a context where all public institutions are summoned by the media to be more accountable to the public opinion, the judicial institutions can hardly avoid taking an interest in what polls and qualitative surveys had to say about the level of public trust (or distrust) in courts and judges. This became particularly true in a context of "penal populism" in which politicians would frequently invoked "claims" from public opinion against the allieged "laxisme" and "un-accoutability" of professional judges. The CSM itself started to wonder about the public opinion commissioning an important survey in 2008 published in a Report quite emblematically entitled "Restoring confidence".

In polls even more than in any statistical inquiry, figures are hard to interpret. Citizens' ordinary relationship with the judiciary is difficult to assess. Not only has the vast majority of them no practical experience of it, but they are also kept at bay from a more immediate understanding of the judiciary by the thick layer of legal language, judicial symbolism and professional rituals. ${ }^{64}$ Just like for political institutions, the expression of an "opinion" on the judiciary requires a level of competence that is very unevenly distributed among the population and is mostly connected to the level of diploma and the social category. In this context, it is hard to know what is exactly measured by polls - if not the continuous saliency of deep-seated clichés on the institution. In any event, polls are probably not able to provide a measure of the public opinion's reaction to the recent transformations of its institutional design -the important rate of non-respondents is actually indicative of the fact that "opinions" are neither consistent, nor stable on the subject matter. Moreover, the

\footnotetext{
${ }^{63}$ Remi Lenoir, La parole est aux juges. Crise de la magistrature et champ journalistique, 101-102 ACTES DE LA RECHERCHE EN SCIENCES SOCIALES 77 (1994).

${ }^{64}$ On this, see Bastien François, Une demande politique de justice. Les Français et la justice, Rapport pour le GIP (1998).
} 
different surveys that have been done in the judiciary seem to bring changing figures from one poll to another: while some polls seem to indicate a decline of the "trust" to historically low levels (55\%), other inquiries -including the one commissioned by the CSM itself- point at very positive opinions $\left(92 \%\right.$ !). ${ }^{65}$ Figures are more meaningful in relative terms. For what it's worth, the level of "trust" in the judiciary (63\%) locates the former in an intermediate position, lower than the one in "public services" (hospital 89\%; school 82\%; army 81\%; police: $76 \%$ ) but quite higher than the "trust" in politicians (elected officials: $44 \%$ ) and the medias (31\%). ${ }^{66}$ With all due precautions mentioned here above, a comparison of polls over time show a relative stability of "trust" during the past decade moving from 63\% in 2008 to 55\% in 2011 and 55\% in 2017. ${ }^{67}$ Beyond the broad and rather undefined question of "trust" (confiance dans la justice) that repeatedly appears in polls, results are probably more interesting when they get to measure differentiated opinions on the concrete "functioning of the judiciary" - which proves to be much more critical. Nothing new here, this is an old phenomenon: already in the late 1970s, two-thirds of the French citizens had a critical view on the subject-matter, ${ }^{68}$ with the persons having had a direct experience of the institution giving more critical views than the other ones. Here again, the figures prove remarkably stable over the time with $35 \%$ of the respondents considering that the judiciary works "well" in 1999 and 37\% in 2017. ${ }^{69}$ Interestingly, this opinion on the judiciary varies a lot along social categories from $32 \%$ among employees to $50 \%$ among "cadres" and intellectual professions.

All in all, however, existing polls do not allow to draw a picture that is much different than the one describing the relation of the public (and its various social components) to other "public institutions". In the end, it is more the political and administrative elites that, as identified in the article, show a distinct distrust vis-à-vis the judiciary - and its mounting claims for autonomy and self-government. As I have tried to show here, successive governments and bureaucracies have proved strikingly resistant to claims as well as attempts aims at positioning the Conseil at the top of the government of the judiciary. While the diminishing legitimacy of the political and the rise of anti-corruption justice have led to reforms granting more importance to the CSM, its many transmission belts with political and administrative spheres have been maintained over time. Here is not the place to identify the blame (or absolve!) - starting with the deep technocratic entrenchment of French governmental elite from the breeding of the Ecole nationale d'administration to

\footnotetext{
${ }^{65}$ Conseil supérieur de la magistrature, Les Français et leur justice. Restaurer la confiance (2008); Laure Cretin, L'opinion des Français sur la justice, 125 InFOSTAT (Jan. 2014).

${ }^{66}$ Id.

67 Ifop, Le regard des Français sur la justice, March 2017: https://www.villagejustice.com/articles/IMG/pdf_114547_-_rapport.pdf.

${ }^{68}$ François, supra note 64.

${ }^{69}$ Id.
} 
ritual passage in ministerial offices. Suffice it to identify here its effects in a deep-seated tendency to over-estimate the risks of judicial independence and to under-estimate the perils related to political subordination. As a result, despite the fact that the CSM has undoubtedly gained competences and institutional autonomy, it remains firmly embedded in a dense web of links and dependences that secure its integration within the body of the State. 